\title{
PEMBUATAN PERTANYAAN AWAL PADA KEGIATAN PRABACA UNTUK MENINGKATKAN KEMAMPUAN MEMBACA INTENSIF
}

\author{
Sumarwati dan Purwadi \\ Program Studi Pendidikan Bahasa dan Sastra Indonesia \\ FKIP Universitas Sebelas Maret \\ Email: watik_uns@ymail.com
}

\begin{abstract}
This study aims to improve the quality of the process and product of intensive reading learning through the use of pre-questions in pre-reading activities. This study was an action research study conducted in three cycles. The participants were Year VIII students of Class C of SMP Penda Mojogedang, Karanganyar Regency. The results showed that there was an improvement in the percentage of the students capable of formulating pre-questions, carrying out intensive reading activities appropriately, answering questions correctly with a percentage of $70 \%$ at the minimum, and showing active and motivated attitudes during the learning process. The effective learning procedure was as follows. The students browsed the text, formulated pre-questions with question words $5 \mathrm{~W}+$ $1 \mathrm{H}$, memorized the pre-questions, read the text intensively to find the answers to the questions, and formulate the answers orally and in writing.
\end{abstract}

Keywords: intensive reading, pre-reading, pre-question

\section{A. PENDAHULUAN}

Pada era globalisasi ini, kemampuan memahami suatu teks tertulis merupakan salah satu keterampilan yang mutlak diperlukan agar tidak tertinggal informasi, mengingat aktivitas membaca dapat diibaratkan sebagai "pembuka jendela dunia" yang berkontribusi besar untuk meningkatkan kualitas diri. Hal ini dapat dikaitkan dengan majunya bidang teknologi informasi dan komunikasi yang begitu pesat sesampai segala peristiwa yang tengah terjadi di tempat jauh pun dengan mudah dan cepat dapat diikuti melalui kegiatan membaca. Tentu saja, untuk meresepsi semua informasi tersebut diperlukan kemampuan memahami teks tulis secara memadai. Maksudnya, isi teks yang dibaca dapat dipahami sesuai dengan maksud penulisnya. Akan tetapi, kemampuan membaca warga masyarakat kita, termasuk para siswa masih memprihatinkan. Sebagaimana hasil pengukuran yang dilakukan oleh PISA atau
Programme for International Student Assestment tahun 2006, suatu survei terhadap literasi membaca, matematika, dan sain pada siswa usia SMP berdasarkan berbagai negara, menunjukkan kemampuan literasi membaca siswa Indonesia ada di urutan 48 berdasarkan 56 negara. Ini merupakan posisi terendah untuk negara-negara di kawasan Asia Tenggara.

Salah satu sekolah yang menghadapi masalah tersebut adalah SMP Penda (Pendidikan Daerah) Mojogedang, Kabupaten Karanganyar, sebuah sekolah swasta di kawasan pedesaan, tepatnya 18 kilometer sebelah utara pusat kabupaten atau 30 kilometer sebelah timur wilayah Kota Surakarta. Hal itu dapat dikaitkan dengan input yang diperoleh satu-satunya SMP swasta di Kecamatan Mojogedang tersebut, yaitu para siswa yang tidak diterima di dua SMP negeri yang ada. Pada tahun ajaran 2009-2010 ini, kesulitan dalam pelajaran membaca intensif atau 
membaca intensif terutama dialami para siswa kelas VIII. Fenomena itu dapat dikaitkan dengan kualitas input siswa pada tahun ajaran 2008/2009 yang dinilai paling rendah dibandingkan tahun ajaran sebelum dan sesudahnya karena mulai tahun itu terdapat penambahan daya tampung, yaitu berdasarkan 2 kelas menjadi 3 kelas. Di antara ketiga kelas tersebut, kualitas siswa kelas VIII C dinilai paling rendah dibandingkan kelas lainnya. Setidaknya hal ini tampak berdasarkan hasil tes membaca intensif pada pelajaran Bahasa Indonesia selama semester genap tahun $2008 / 2009$. Hanya $40 \%$ sampai $60 \%$ berdasarkan 40 siswa yang mendapat nilai $70 \mathrm{ke}$ atas. Selain itu, hasil tes membaca pertama sampai keempat tidak ada peningkatan kemampuan membaca. Padahal, semestinya dengan semakin banyak berlatih membaca, kemampuan siswa menjadi semakin meningkat.

Rendahnya kemampuan memahami bacaan para siswa menunujukkan adanya kelemahan dan kesulitan dalam belajar membaca, yang dalam hal ini terutama pada membaca intensif, yang menurut Brown adalah kegiatan membaca dengan penuh penghayatan untuk menyerap pesan yang ada dalam teks (2001:297). Mengenai masalah tersebut, guru Bahasa Indonesia mengidentifikasi penyebab siswa 'gagal' dalam belajar membaca berkaitan dengan kesulitan memahami pikiran utama atau ide pokok dalam bacaan, selain rendahnya minat dan motivasi mereka dalam belajar membaca. Berdasarkan pengamatan guru dan wawancara dengan siswa diperoleh informasi mengenai penyebab siswa sulit memahami isi sebuah bacaan, yakni mereka kurang mampu menyeleksi bagian-bagian yang penting dan kurang penting. Oleh karena itu, mereka memberikan porsi perhatian yang sama pada semua bagian bacaan sesampai selain waktu yang dibutuhkan untuk membaca lebih lama, juga kesulitan dalam mengidentifikasi gagasan utama. Ini terlihat pada saat siswa dihadapkan pada soal pilihan ganda berkaitan dengan gagasan utama tiap paragraf atau sebuah bacaan. Dalam pandangan mereka semua pilihan jawaban adalah benar atau sama isinya sesampai mengalami kesulitan menentukan jawaban paling tepat dan akibatnya hasil tes membaca intensifnya rendah. Karena itu, para siswa memiliki anggapan bahwa pelajaran membaca merupakan pelajaran yang sulit dan tidak disukai dan membuat mereka pasif selama proses pembelajaran. Padahal, selama ini guru sudah memilihkan teks dengan tingkat kesulitan yang lebih mudah berdasarkan yang seharusnya sebagai upaya mengatasi kesulitan membaca pada siswa.

Berdasarkan diskusi dengan dua guru Bahasa Indonesia (Siti Mulyani dan Suyatmin, S.Pd.) diperoleh informasi bahwa selama ini pembelajaran membaca intensif dilakukan dengan prosedur sebagai berikut: (1) memberi sebuah teks berbahasa Indonesia yang diambil berdasarkan berbagai sumber, selain berdasarkan buku teks atau LKS (lembar kerja siswa) dengan alasan soal-soal dalam bacaan yang ada pada dua sumber belajar tersebut sudah diisi oleh siswa, (2) meminta siswa membaca teks tersebut dalam waktu yang ditentukan guru, misalnya 15 menit, (3) meminta siswa mencari kata-kata yang dinilai baru/sukar untuk dibahas bersama, (4) menugasi beberapa siswa untuk menyampaikan isi bacaan, (5) menugasi siswa mengerjakan soal (pilihan ganda atau isian) yang dibuat guru pada buku tugas, (7) mengumpulkan buku tugas, (8) membahas jawaban soal-soal tersebut, serta (9) menilai hasil tes membaca. Langkah pembelajaran tersebut menunjukkan bahwa siswa tidak diberi kesempatan melakukan aktivitas membaca melalui proses yang seharusnya, yaitu ada tahap prabaca lebih dahulu, kemudian tahap membaca, baru tahap pascabaca. Itu berarti kegiatan membaca yang dilalui siswa selama ini adalah langsung pada tahap membaca dan diikuti tahap pascabaca.

Prabaca merupakan kegiatan yang dilakukan sebelum aktivitas membaca sesungguhnya (kegiatan inti membaca) dengan tujuan memperoleh gambaran awal guna membangun skemata tentang isi bacaan. Menurut Porter (Frase, Patrick, \& Schumer, 
2000:52), melalui prabaca, siswa dapat mengaktivasi pengetahuan awalnya dalam rangka merekonstruksi pemahaman baru (sejalan dengan prinsip-prinsip dalam pembelajaran konstruktivistis). Karena itu, pelaksanaan prabaca penting dilatihkan kepada siswa sebelum mereka diberi tugas membaca agar kemampuannya dalam memahami suatu teks dapat meningkat.

Untuk mengaktivasi pengetahuan awal, ada beberapa strategi yang dapat diterapkan, yakni melalui pemberian gambaran awal, pembuatan peta semantik, diskusi kelas, dramatisasi, serta pembuatan pertanyaan awal (Frase, Patrick, \& Schumer, 2000:53). Teknik pelaksanaan prabaca dengan pemberian gambaran awal dilakukan dengan guru memberi gambaran secara umum mengenai topik yang akan dibahas. Prabaca dengan pembuatan peta semantik yakni guru menuliskan kata atau frase kunci yang terdapat dalam teks dan ditemukan berdasarkan kegiatan membaca sekilas, kemudian membuat hubungan-hubungan yang logis antara kata atau frase tersebut. Prabaca dengan diskusi kelas dilakukan dengan membicarakan berbagai hal mengenai topik utama dalam teks, baik secara klasikal maupun kelompok. Prabaca dengan dramatisasi berarti memeragakan apa yang ada dalam teks. Adapun prabaca dengan pembuatan pertanyaan awal dilakukan dengan membuat pertanyaan untuk dijawab melalui membaca teks secara intensif. Berdasarkan berbagai strategi tersebut, guru dan peneliti memilih pembuatan pertanyaan awal dengan alasan strategi tersebut dapat dilakukan siswa secara mandiri sesampai lebih memungkinkan untuk dlakukannya setiap kali melakukan aktivitas baca, sedangkan yang lainnya cenderung bergantung pada peran guru atau orang lain. Selain itu, strategi yang lain memerlukan waktu lebih lama dalam pelaksanaannya.

Pertanyaan awal adalah pertanyaanpertanyaan yang dibuat berdasarkan (1) hasil membaca judul serta sub-subjudul dan atau (2) hasil membaca sekilas sebagian atau seluruh teks, yang akan dijawab melalui aktivitas membaca secara intensif (Shanahan, 1997:241). Dengan demikian, pembaca dapat memberikan porsi perhatian yang berbeda pada bagian-bagian teks. Tentunya fokus perhatian akan lebih banyak diarahkan pada bagian yang berkaitan dengan pertanyaan. Oleh karenanya, hasil penelitian Keally, Bakriwala, dan Sheridan (2003) menunjukkan bahwa pengadaan pertanyaan awal pada kegiatan prabaca paling mudah diterapkan dalam pembelajaran membaca dan efektif dalam meningkatkan kemampuan memahami bacaan pada siswa yang mengalami kesulitan membedakan gagasan utama dan pendukung. Adapun tipe pertanyaan yang biasa digunakan adalah pertanyaan berpola $5 \mathrm{~W}+1 \mathrm{H}$ (apa, siapa, di mana, kapan, mengapa, dan bagaimana) yang dibuat siswa di bawah bimbingan guru, namun pertanyaan tersebut lebih banyak mengarah pada aspek pemahaman, bukan ingatan. Sebagaimana dicontohkan Bernhardt untuk bacaan yang berupa artikel berjudul The New Star karya G. Wells dapat dibuat pertanyaan awal sebagai berikut: Terbentuk berdasarkan senyawa apa bintang baru itu? Di mana letak bintang baru itu? dan Mengapa bintang itu tampak semakin terang? (1991: 62).

Merefleksi fenomena di atas, peneliti bersama guru Bahasa Indonesia menetapkan untuk mengadakan pertanyaan awal pada kegiatan prabaca dalam bentuk penelitian tindakan kelas dengan subjek siswa kelas VIII C. Kegiatan penelitian ini merupakan satu upaya mengefektifkan pembelajaran membaca intensif pada siswa SMP Penda Mojogedang agar prestasi yang dicapai dapat meningkat. Namun demikian, perlunya kegiatan penelitian ini juga didasari oleh alasan: (1) pemahaman terhadap kebutuhan siswa, termasuk kebutuhannya untuk menguasai berbagai strategi membaca, dapat mencegah munculnya sikap frustasi yang seringkali membawa mereka ke perilaku negatif (menjadi bosan dan tidak menyukai pelajaran membaca, bahkan pelajaran Bahasa Indonesia), (2) berbagai upaya untuk mengatasi kesulitan belajar membaca harus selalu diadakan agar siswa tidak mengalami hambatan dalam memaknai 
ide tertulis, yang dapat berimplikasi pada literasi membacanya, dan (3) masalah peningkatan prestasi belajar membaca para siswa SMP merupakan masalah bersama, bukan hanya tanggung jawab sekolah, sesampai semua komponen masyarakat, termasuk perguruan tinggi harus senantiasa aktif dan kreatif dalam menjalankan perannya.

Tujuan pelaksanaan penelitian ini adalah untuk meningkatkan kualitas proses (aktivitas dan motivasi) siswa dalam pembelajaran membaca intensif dan kemampuan memahami bacaan siswa kelas VIII C SMP Penda Mojogedang melalui pengadaan pertanyaan awal pada kegiatan prabaca. Untuk mengukur ketercapaian tujuan di atas dirumuskan indikator-indikator ketercapaian tujuan. Berdasarkan kondisi dan hasil pembelajaran membaca sebelumnya serta waktu yang tersedia,tolok ukur indikatornya dirumuskan pada tabel 1 .

Tabel 1: Tolok Ukur Ketercapaian Tujuan Penelitian

Aspek

Capaian

Cara mengukur minimal

Kemampuan siswa dalam membuat $75 \% \quad$ Diukur pada saat pembelajaran dan dihitung

pertanyaan awal dengan kata tanya berdasarkan persentase siswa yang dapat membuat

$5 \mathrm{~W}+1 \mathrm{H}$ berdasarkan hasil membaca seki- pertanyaan awal dengan kata tanya $5 \mathrm{~W}+1 \mathrm{H}$

yang relecan dengan isi teks

1 a s

Kemampuan siswa dalam melaku$75 \%$ Diamati saat pembelajaran dan dihitung berdasarkan

kan aktivitas membaca intensif sepersentase siswa yang melakukan aktivitas

c a r a b e $\mathrm{n} \mathrm{a} \mathrm{r}$ baca secara benar, yaitu memusatkan perha- tian terhadap teks dan tidak membaca mundur

Kemampuan siswa dalam mema$70 \% \quad$ Diukur berdasarkan hasil tes membaca dan dihitung

$$
\mathrm{h} \mathrm{a} \mathrm{m} \mathrm{i} \mathrm{i} \mathrm{s} \mathrm{i} \mathrm{t} \mathrm{e} \mathrm{k} \mathrm{s}
$$

berdasarkan persentase siswa yang dapat menjawab

dengan benar $70 \%$ soal bacaan

Keaktifan dan keantusiasan siswa $75 \%$ Diamati saat pembelajaran dan dihitung berdasarkan

dalam pembelajaran membaca persentase siswa yang menampakkan keaktif-

an dan keantusiasan selama pembelajaran

Pada dasarnya, membaca merupakan analisis bacaan. Sebagaimana dinyatakan olehCarrell (1999:17) bahwa membaca adalah memahami ide/gagasan yang tersurat maupun tersirat dalam bacaan. Jadi, proses membaca itu menuju pada pemahaman. Menurut hasil penelitian Solan, Shelley-Tremblay, Hansen \& Larson (2007) proses membaca dapat divisualisasikan dalam gambar 1 berikut ini.

Gambar 1: Bagan proses membaca

Melalui bagan tersebut Solan, ShelleyTremblay, Hansen, \& Larson (2007: 18) membuktikan betapa rumitnya proses membaca karena melibatkan aktivitas mengingat kembali, menilai, membayangkan, mengorganisasi, meenerapkan, dan memecahkan masalah. Dengan kata lain, membaca adalah suatu proses berpikir. Tindakan untuk mengenal makna tanda baca, kata, frase, dan kalimat yang disimbolkan secara tertulis memerlukan interpretasi. Selain itu, pembaca harus menggunakan semua informasi yang ada pada ingatannya untuk membuat kesimpulan secara kritis dan kreatif, menyelami maksud penulis, dan mengevaluasi 
gagasan yang disajikan dalam teks. Kesemuanya itu dilakukan untuk mencapai tujuan akhir, yaitu pemahaman.

Menurut Goodman, Burke, dan Sherman (1980:15), membaca intensif membatasinya sebagai suatu proses merekonstruksi pesan yang terdapat dalam teks yang dibaca. Lebih lanjut dinyatakan bahwa proses merekonstruksi pesan itu sifatnya berlapis dan interaktif serta terjadi proses pembentukan dan pengujian hipotesis. Maksudnya, pesan digali melalui lapisanlapisan makna yang terdapat dalam teks. Melalui interaksi dengan makna yang terdapat dalam teks, pembaca akan membuat dan menguji hipotesis. Berdasarkan hasil pengujian hipotesis tersebut, pembaca dapat menarik suatu kesimpulan.

Berkenaan dengan proses pemahaman bacaan, Pearson dan Johnson (Nunan, 1992:6667) menyatakan bahwa inti pemahaman berkaitan dengan satu prinsip yang sederhana, yaitu sebagai upaya membangun jembatan antara yang baru dengan yang sudah diketahui. Oleh karenanya, ada beberapa prinsip penting dalam aktivitas membaca intensif. Pertama, pemahaman merupakan proses aktif, bukan pasif. Adapun aktivitas itu tidak lain berdasarkanpada menafsirkan apa yang dibaca sesuai dengan pengetahuan yang telah dimiliki mengenai topik yang dibacanya. Dengan demikian, pemahaman bukan sekedar masalah merekam secara harfiah tentang apa yang dibaca (mengingat), tetapi mengarah pada menganalisis, menyintesis, mengevaluasi, serta mengaplikasi. Ke dua, pemahaman memerlukan sejumlah besar pengambilan keputusan atau kesimpulan. Aktivitas ini sudah pasti memerlukan pemikiran yang kritis dan logis sesampai seringkali seorang pembaca kesulitan atau kebingungan tatkala harus membuat kesimpulan terhadap suatu bacaan yang sederhana sekalipun. Ketiga, pemahaman merupakan aktivitas dialog antara pembaca dan penulis. Oleh karenanya, pembaca yang baik tidak hanya menafsirkan apa yang ada dalam bacaan berdasarkan persepsinya sendiri, tetapi harus berupaya memaknainya seperti yang dimaksud penulisnya sesampai tidak terjadi misinterpretasi.

Sebagai upaya menumbuhkembangkan suatu keterampilan, pembelajaran membaca akan efektif apabila didukung oleh faktorfaktor baik yang berasal berdasarkan dalam diri siswa sendiri maupun berdasarkan luar siswa. Faktor berdasarkan dalam diri siswa yang dapat mendorong siswa aktif membaca adalah tumbuhnya motivasi. Ini dapat dibangkitkan dengan cara pemberian pembelajaran membaca yang menarik sesampai dapat menumbuhkan minat dan motivasi siswa. Mengenai hal ini, berdasarkan hasil penelitian Guthrie, Laurel, Stephen, \& Nicole (2007) diperoleh fakta bahwa melibatkan siswa dalam pemilihan cerita dan biografi tokoh yang diidolakan dapat meningkatkan motivasi siswa dalam pembelajaran membaca narasi. Selain itu, pembelajaran membaca menjadi efektif apabila didukung oleh faktor eksternal yang berupa lingkungan yang dapat memacu siswa untuk dapat menggunakan bahasanya secara reseptif. Menurut penelitian Devine (1993), lingkungan merupakan faktor yang paling berpengaruh terhadap peningkatan kemampuan membaca siswa.

Berdasarkan uraian di atas, sudah saatnya bagi guru bahasa Indonesia, khususnya guru SMP untuk menerapkan pembelajaran membaca yang memberi peluang siswa untuk mengembangkan kemampuan membacanya dengan berbagai strategi dan media. Selain itu, sebagai suatu keterampilan, semakin sering siswa diberi kesempatan berlatih tentulah mereka akan makin terampil dalam membaca. Dengan demikian, dalam pengajaran membaca para siswa haruslah diberi kesempatan secara luas untuk mengembangkan aktivitas dan kreativitasnya agar tujuan pengajaran tersebut, yakni agar siswa terampil membaca, dapat terwujudkan.

Pertanyaan merupakan hal yang biasa diadakan dalam pembelajaran, namun umumnya diadakan untuk mengukur kemampuan siswa dalam memahami materi sesampai pemberian pertanyaan dilakukan setelah selesai penyampaian materi. Padahal, 
pertanyaan memiliki efek yang menguntungkan, baik yang diberikan sebelum maupun sesudah penyampaian materi atau lazim diistilahkan dengan prequestion dan postquestion. Seperti dinyatakan Thalheimer (2003:4), kalau pertanyaan yang diadakan sebelum pembelajaran disebut prequestion atau pertanyaan awal, tetapi kalau pertanyaan diadakan setelah pembelajaran disebut postquestion yang wujudnya bisa berupa kuis, tes, atau ujian. Adapun fungsinya, pertanyaan awal dapat memfokuskan perhatian siswa terhadap konsep-konsep penting pada materi pelajaran selama pembelajaran berlangsung, sedangkan postquestion dapat mengingat kembali hal-hal yang dilupakan siswa serta menjadi balikan bagi pemahaman terhadap materi yang telah disampaikan. Dan hal itu juga berlaku pada pembelajaran membaca.

Pertanyaan awal yang diadakan pada tahap prabaca dapat membantu siswa untuk memfokuskan perhatiannya pada informasiinformasi yang ditargetkan oleh pertanyaan itu selama membaca. Misalnya sebelum pelaksanaan tahap inti membaca teks tentang "dinosaurus", diadakan perumusan pertanyaan "bagaimana dinosaurus punah", "mengapa kerangkanya banyak ditemukan di wilayah kutub utara", sesampai para siswa memberi perhatian lebih banyak terhadap materi yang berkaitan dengan pertanyaan tersebut (Thalheimer, 2003:5). Mengenai tipe pertanyaan yang digunakan, Watts \& Anderson. (2001: 5) menyampaikan bahwa pertanyaan pada prabaca maupun pascabaca mencakup pertanyaan yang sejajar dengan kata tanya apa, siapa, di mana, kapan, mengapa dan bagaimana $(5 \mathrm{~W}+1 \mathrm{H})$. Namun lebih lanjut dinyatakan, pada prabaca pertanyaan lebih difokuskan pada upaya membelajarkan siswa dalam hal membaca, sedang pertanyaan pascabaca lebih diarahkan pada upaya memperdalam pemahaman siswa tentang segala macam informasi yang diperoleh berdasarkan teks. Dengan demikian, ada perbedaan tipe pertanyaan antara kedua jenis pertanyaan.

Berdasarkan uraian di atas dapat dirumuskan kerangka pemikiran sebagai berikut ini. Para siswa kelas VIII C mengalami kesulitan dalam memahami teks karena kurang mampu membedakan gagasan utama dan gagasan pendukung. Oleh karenanya, semua bagian teks, kata demi kata, frase demi frase, dan kalimat demi kalimat dengan porsi perhatian yang sama.. Kondisi tersebut tidak terlepas berdasarkan strategi pembelajaran yang selama ini diterapkan, yaitu para siswa belum dilatih membaca melalui tahap prabaca terlebih dahulu. Padahal, tahap tersebut sangat penting karena melalui tahap itu siswa akan mendapatkan gambaran awal tentang apa yang akan dibacanya. Salah satu teknik yang dinilai efektif dan efisien dalam tahap prabaca adalah pengadaan pertanyaan awal, yakni pertanyaan yang berkaitan dengan isi teks yang dirumuskan siswa bersama guru setelah membaca sekilas teks. Pertanyaan itu ditekankan pada bagianbagian penting dalam teks. Melalui aktivitas tersebut, siswa akan dapat mengatur porsi perhatian pada bagian per bagian dalam teks yang dibacanya. Maksudnya siswa akan memberikan fokus perhatian yang lebih banyak pada bagian bacaan yang berkaitan dengan pertanyaan, sebaliknya lebih sedikit pada bagian lain yang kurang penting Dengan strategi tersebut, siswa lebih mudah dalam mengkonstruksi konsep-konsep pada tahap membaca sesampai kemampuan membacanya meningkat. Bila digambarkan dalam bagan, pemikiran tersebut dapat divisulaisasikan pada gambar 2 . penelitian

Gambar 2: Bagan kerangka pikir

\section{B. METODE PENELITIAN}

Penelitian ini dilakukan di SMP Penda (Pendidikan Daerah) Mojogedang, Kabupaten Karanganyar, yang merupakan sekolah swasta. Lokasinya berada di kawasan pedesaan, tepatnya di Kecamatan Mojogedang. Tahap persiapan sampai pelaporan hasil penelitian dilakukan selama 7 bulan, yakni mulai bulan Mei sampai dengan November 2009. Tahap perencanaan dilaksanakan pada bulan Mei 
sampai dengan Agustus. Adapun pelaksanaan pembelajaran diselenggarakan pada setengah semester gasal (semester 1), yaitu bulan September dan Oktober 2009.

Yang menjadi subjek penelitian ini adalah siswa kelas VIII C SMP Penda Mojogedang pada tahun ajaran 2009/2010 dengan jumlah siswa 40 orang. Secara umum, mayoritas siswa SMP Penda Mojogedang berasal berdasarkan keluarga petani yang dalam kehidupan sehari-harinya menggunakan bahasa Jawa, baik di rumah maupun di luar rumah, bahkan di sekolah. Hal tersebut sangat berpengaruh terhadap penguasaannya pada kosa kata dan srtuktur kalimat bahasa Indonesia sesampai berdampak pula terhadap kemampuan siswa dalam menangkap pesan suatu teks berbahasa Indonesia.

Pengumpulan data yang berupa tingkat keaktifan, keantusiasan, dan partisipasi siswa dalam membuat pertanyaan awal dilakukan dengan teknik observasi oleh kolaborator selama proses pembelajaran. Data yang berupa tingkat kemampuan membaca intensif siswa diukur dengan tes membaca pada akhir pembelajaran. Karena itu, instrumen yang digunakan adalah pedoman observasi yang berupa ceklis dan tes (pilihan dan isian).

Dalam pelaksanaan PTK ini, mekanisme kerjanya diwujudkan dalam bentuk siklus (ada 3 siklus), yang setiap siklusnya mencakup 4 kegiatan, yaitu (1) perencanaan, (2) pelaksanaan, (3) observasi dan interpretasi, dan (4) analisis dan refleksi. Karena pelaksanaan pembelajaran membaca intensif ini dilakukan melalui tahap prabaca (membaca sekilas bacaan kemudian membuat pertanyaan awal), tahap membaca secara intensif, dan tahap pascabaca (menjawab soal bacaan), pelaksanaan tindakan setiap siklus meliputi tiga tahap tersebut.

\section{PEMBAHASAN}

C. HASIL PENELITIAN DAN

Dalam pelaksanaan pembelajaran, materi teks diambil berdasarkan beberapa sumber, yaitu koran dan majalah siswa, tidak berdasarkan buku teks karena sebagian siswa sudah membaca teks yang ada di dalamnya, bahkan mengerjakan soal-soalnya. Untuk setiap satu kali pembelajaran digunakan dua teks, yaitu satu untuk berlatih dan satu teks untuk evaluasi. Pemilihan teks disesuaikan dengan kompetensi dasar (KD) pembelajaran dan minat siswa. Adapun hasil pelaksanaan tiga siklus penelitian ini dapat dibuat rekapitulasi capaiannya pada tabel 2 .

Tabel 2: Rekapitulasi ketercapaian indikator penelitian pada 3 siklus tindakan

$$
\begin{array}{lllllllll}
\mathrm{I} & \mathrm{n} & \mathrm{d} & \mathrm{i} & \mathrm{k} & \mathrm{a} & \mathrm{t} & \mathrm{o} & \mathrm{r}
\end{array}
$$

Persentase capaian

\section{Siklus I Siklus II Siklus III}

Siswa yang mempu merumuskan pertanyaan awal dengan $\quad 45 \% \quad 67,5 \%$ $80 \%$

kata tanya $5 \mathrm{~W}+1 \mathrm{H}$ berdasarkan hasil membaca sekilas teks

Siswa yang mampu melakukan aktivitas membaca intensif $\quad 47,5 \% \quad 60 \%$ $70 \%$

secara benar

Siswa yang mampu memahami isi bacaan (mengerjakan $\quad 50 \% \quad 77.5 \%$ $82,5 \%$

$70 \%$ soal bacaan secara benar)

Siswa yang aktif dan antusias dalam pembelajaran membaca $\quad 50 \% \quad 67,5 \%$ $80 \%$

Data pada tabel 2 dapat menunjukkan bahwa pada siklus I ketercapaian indikator pertama merupakan yang paling rendah, yakni persentase siswa yang mampu membuat pertanyaan awal dengan kata tanya apa, siapa, di mana, kapan, mengapa, dan bagaimana. Hanya ada $45 \%$ (18 orang) yang dapat membuat pertanyaan awal di atas tingkat 
ingatan yang relevan dengan isi teks. Sebagian besar siswa hanya membuat pertanyaan tingkat ingatan (apa, siapa, dan di mana) karena pembuatan pertanyaan awal hanya didasarkan pada judul dan subjudul dalam teks. Hal itu dilakukan siswa karena mereka Akan tetapi, pada siklus II persentase siswa yang mampu membuat pertanyaan awal sampai tingkat pemahaman meningkat, bahkan pada siklus III mencapai hampir 2 kali lipat berdasarkan siklus I setelah pembuatannya dilakukan di bawah bimbingan guru secara intensif dan berkelompok ( 2 orang).

Peningkatan persentase ketercapaian pada indikator kedua menunjukkan yang paling rendah dibandingkan tiga indikator lain, yakni sebagian siswa belum mampu melakukan aktivitas membaca intensif secara benar karena perhatian mereka tidak sepenuhnya terfokus pada teks selama membaca. Mereka sesekali membaca pertanyaan awal yang dicatatnya, kemudian melanjutkan aktivitas membacanya atau setelah melihat catatan. sebagian siswa ada kalanya juga membaca mundur. Karena itu, pada siklus II mereka diminta mengingat-ingat pertanyaan awalnya sebelum membaca teks secara intensif dan guru melakukan pemantauan lebih intensif terhadap perilaku membaca siswa. Namun demikian, sampai siklus III pun masih ada $25 \%$ siswa yang belum membaca intensif dengan benar (target belum tercapai). Oleh karenanya, guru melanjutkan tindakan meskipun tidak dalam rangka melakukan penelitian.

Secara keseluruhan, berdasarkan data pada tabel 2 dapat dinyatakan bahwa terjadi peningkatan persentase ketercapaian pada keempat indikator dalam penelitian ini (berdasarkan siklus I sampai siklus III). Peningkatan tertinggi adalah pada indikator pertama dan ketiga, yaitu bertambahnya jumlah siswa yang mampu merumuskan pertanyaan awal berdasarkan hasil membaca sekilas isi teks dan yang mampu memahami isi bacaan. Untuk indikator pertama, yang bisa membuat pertanyaan awal pada siklus I hanya $47,5 \%$ siswa (19 orang), namun pada siklus III sudah mencapai $80 \%$ (32 orang). Untuk indikator ketiga, yang mampu menjawab $70 \%$ soal bacaan dengan benar pada siklus I hanya 50\% (20 orang), tetapi pada siklus III menjadi 82,5\% (33 orang). Berdasarkan hasil penelitian ini dapat dirumuskan pembahasannya sebagai berikut ini.

\section{Pembuatan pertanyaan awal} tingkat pemahaman sampai tingkat analisis dimungkinkan melalui membaca sekilas isi teks.

Berdasarkan hasil pelaksanaan tindakan siklus I, sebagain besar siswa tidak membaca sekilas isi bacaan tetapi hanya membaca judul dan subjudul sesampai tipe pertanyaan yang dibuat hanya bersifat ingatan. Tentu saja hal tersebut tidak sesuai dengan tujuan penelitian tindakan ini, yakni mengarah pada pemahaman bacaan sesampai pertanyaan awal yang dirumuskan mestinya minimal pada tingkatan pemahaman. Ini sejalan dengan pendapat Thalheimer (2003:5) bahwa pemakaian pertanyaan prabaca akan lebih bermanfaat jika mencakup pertanyaan level lebih tinggi, yaitu berdasarkan tipe pemahaman dan aplikasi, dan pertanyaan yang penting secara struktural. Dinyatakannya siswa akan memperoleh keuntungan yang besar berdasarkan pertanyaan semacam itu. Adapun pembagian tipe-tipe pertanyan tersebut mengacu pada Bloom yang membedakannya sebagai berikut: (1) tipe ingatan, pemahaman, (3) aplikasi, (4) analisis, (5) sintesis, dan (6) evaluasi (Bloom, et al.,1984). Oleh karenanya, pada penelitian ini siswa didorong untuk membuat pertanyaan awal paling tidak pada tingkat pemahaman.

Strategi yang ditempuh untuk menagkomodasi agar pertanyaan awal buatan siswa mengarah pada tingkat pemahaman serta tingkat di atasnya dilakukan dengan cara meminta siswa tidak hanya membaca judul tetapi, membaca sekilas isi teks terlebih dahulu. Hasilnya, pada siklus II dan III sebagian besar siswa dapat membuat pertanyaan awal tingkat pemahaman sampai analisis. Itu menunjukkan dengan membaca sekilas, siswa memiliki informasi yang memadai untuk membuat 
pertanyaan awal minimal pada tingkat pemahaman.

2. Pembuatan pertanyaan awal tingkat pemahaman sampai level di atasnya dapat dioptimalkan melalui bimbingan guru secara intensif dan kerja kelompok.

Pertanyaan pada prabaca yang disusun siswa secara mandiri umumnya lebih mengarah pada tipe ingatan atau pada fakta-fakta yang sangat mudah untuk dijawab (Dole, Valencia, Greer, \& Waldrop, 1991:157). Hal tersebut juga terjadi pada subjek penelitian ini. Pada siklus I, ketika siswa membuat pertanyaan awal secara mandiri terhadap teks tentang biografi tokoh, hasilnya sebagian besar pertanyaan yang dibuat mengarah pada tingkat ingatan, yakni menanyakan hal yang umum mengenai tokoh yang dibicarakan dalam teks dengan kata tanya siapa, di mana, dan kapan. Oleh karenanya, kalimat tanya yang dibuat adalah Siapakah Iwan Fals? Di mana dia pertama kali menyanyi? Kapan mulai menjadi penyani? Akan tetapi, setelah siswa menyusunnya dengan bimbingan guru dan bersama temannya (siklus II dan III), terjadi peningkatan kualitas pertanyaan yang dibuatnya, yakni sudah banyak yang bertipe pemahaman, aplikasi, dan analisis. Fenomena tersebut selaras dengan temuan Readence, Moore, \& Rickelman (2000: 67) bahwa untuk mencegah hal itu, guru harus memberikan bimbingan dengan cara meminta siswa membuat pertanyaan yang menggunakan kata tanya mengapa dan bagaimana. Misalnya pada siklus II, berdasarkan judul bacaan "Politik Uang pada Pileg (Pemilihan Anggota Legislatif)", dapat dibuat pertanyaan: Bagaimana hal itu dilakukan? Mengapa caleg melakukan hal itu? Bagaimana dampak terhadap kinerjanya kalau caleg tersebut terpilih?

Selain dengan bimbingan guru, pembuatan pertanyaan awal yang dilakukan bersama teman juga terbukti lebih baik berdasarkanpada dibuat secara mandiri. Sebagaimana yang dilakukan pada siklus II dan III, siswa membaca sekilas dan membuat pertanyaan awal dalam kelompok kecil, yaitu terdiri atas 2 orang. Kondisi ini dapat dikaitkan dengan hasil penelitian Guthrie, Laurel, Stephen, \& Nicole (2007) yang menyimpulkan bahwa mengondisikan siswa untuk berbagi bacaan sekaligus memberi komentar terhadap bacaan tersebut dengan temannya dapat meningkatkan motivasi dalam pembelajaran membaca. Secara logis dapat dinyatakan bahwa pembelajaran membaca akan efektif apabila didukung oleh faktor-faktor baik, yang berasal berdasarkan dalam diri sendiri maupun berdasarkan luar siswa. Faktor internal yang dapat mendorong siswa aktif membaca adalah tumbuhnya motivasi. Ini dapat dibangkitkan dengan cara pemberian pembelajaran membaca yang menarik sesampai dapat menumbuhkan minat dan motivasi siswa dan salah satunya adalah bekerja berkelompok.

3. Pengadaan pertanyaan awal meningkatkan pemahaman terhadap isi teks.

Dengan memperhatikan data pada tabel 2 dapat disimpulkan bahwa seiring dengan meningkatnya persentase siswa yang mampu membuat pertanyaan awal menunjukkan adanya peningkatan persentase siswa yang mampu memahami bacaan, yakni yang memperoleh nilai tes minimal 70. Selain itu, hasil pembandingan data pada indikator pertama dan ketiga untuk setiap siswa menunjukkan adanya korelasi antara keberhasilan dalam membuat pertanyaan awal dengan tingkat pemahaman terhadap isi bacaan. Hal ini relevan dengan hasil penelitian Dole, Valencia, Greer, \& Waldrop (1991) yang melakukan pengujian terhadap efek bacaan yang pada bagian awalnya diberi pertanyaan awal dengan yang tidak diberi terhadap tingkat pemahaman siswa dan ditemukan para siswa yang diberi bacaan dengan pertanyaan awal lebih tinggi tingkat pemahamannya. Selain itu, juga dengan kajian Hartley \& Davies (2006) dan Pressley, Wood, Woloshyn, Martin, King, \& Deborah (2001: 100) terhadap dua kelompok siswa yang diberi teks dengan tingkat kesulitan tinggi, namun hanya satu kelompok yang diberi pertanyaan awal, menunjukkan 
tingkat pemahaman lebih tinggi pada kelompokitu.

Pertanyaan awal yang diadakan pada tahap prabaca dapat membantu siswa untuk memfokuskan perhatiannya pada informasiinformasi yang ditargetkan oleh pertanyaan itu selama membaca. Misalnya sebelum pelaksanaan tahap inti membaca teks tentang "dinosaurus", diadakan perumusan pertanyaan "bagaimana dinosaurus punah", "mengapa kerangkanya banyak ditemukan di wilayah kutub utara", sesampai siswa memberi perhatian lebih banyak terhadap materi yang berkaitan dengan pertanyaan tersebut. Ini sesuai dengan hasil penelitian Wright dan Kendall (Thalheimer, 2003:10) yang menemukan bahwa pengadaan pertanyaan awal dapat meningkatkan hasil belajar membaca yang dicapai siswa antara 15 sampai $20 \%$. Adapun kajian Devine (1993) menemukan pertanyaan awal yang diadakan dalam pembelajaran membaca teks yang sulit, menghasilkan peningkatan hasil belajar membaca. Selain itu, hasil eksperimen Rickards (1976) menemukan bahwa pertanyaan awal yang bersifat umum dan difokuskan pada informasi yang benar-benar penting atau utama secara signifikan dapat mengembangkan pemahaman siswa Bahkan, Bangert-Drowns, Kulik, \& Morgan (1991) menemukan pengadaan pertanyaan awal dapat meningkatkan hasil belajar membaca sampai $40 \%$.

4. Pembuatan pertanyaan awal merupakan upaya melatih siswa berpikir kritis.

Dengan membuat pertanyaanpertanyaan sebelum melakukan kegiatan membaca yang sesungguhnya, memungkinkan siswa untuk melakukan aktivasi pikirannya sesampai mereka berada dalam kondisi lebih siap untuk meresepsi isi teks yang dibacanya.. Sebagaimana dinyatakan oleh Harvey \& Goudvis, 2007:82) bahwa dengan melatih siswa membuat pertanyaan sebelum membaca secara intensif suatu teks merupakan cara untuk mengondisikan mereka menjadi pembaca yang senantiasa berpikir kritis dan mandiri. Hal itu disebabkan aktivitas merumuskan pertanyaanpertanyaan tersebut mendorong siswa untuk mengaktivasi pengetahuan awalnya, melakukan prediksi-prediksi, juga mengaktivasi rasa ingin tahunya tentang isi teks. Fenomena tersebut juga terjadi pada subjek penelitian ini, yakni pada siklus II dan III sebagian siswa (lebih berdasarkan 40\%) membuat pertanyaan awal lebih banyak berdasarkan yang diminta guru karena topik bacaannya merupakan hal baru dan relevan dengan lingkungan mereka (budidaya tanaman yang menguntungkan, yaitu straberi, anthurium, dan durian). Pertanyaan yang banyak itu tidak hanya merefleksikan kurangnya pengetahuan siswa tentang topik dalam teks, tetapi juga merefleksikan rasa ingin tahu yang besar terhadap isi teks tersebut. Karena itulah, pada siklus II dan III berupaya membaca dengan sungguh-sungguh isi teks dalam mendapatkan informasi atau jawaban terhadap pertanyaan awal sesampai sesekali perlu membaca pertanyaan yang ditulisnya untuk mengecek pertanyaan yang sudah ditemukan jawabannya dan yang belum. Meskipun demikian, sebagian besar siswa dapat menjawab $70 \%$ soal bacaan secara tepat. Hal ini dapat dikaitkan dengan penelitian Watts \& Anderson (2001) yang menemukan bahwa dengan dirumuskannya pertanyaan awal oleh siswa, ternyata respon yang baik tidak hanya diberikan siswa terhadap pertanyaanpertanyaan yang menjadi pertanyaan awal, tetapi juga pada pertanyaan-pertanyaan lain yang muncul dalam pikirannya.

5. Pembuatan pertanyaan awal merupakan realisasi aktivitas membaca melalui proses yang benar.

Hasil tindakan dalam penelitian ini (lihat data pada tabel 2) menunjukkan bahwa pembelajaran membaca dengan melatih siswa melakukan aktivitas membaca yang diawali dengan tahap prabaca, kemudian tahap membaca secara intensif, baru dilanjutkan dengan tahap pascabaca dapat meningkatkan 
kualitas proses dan hasil pembelajaran tersebut. Ini berarti, dalam pembelajaran membaca yang bertujuan menumbuhkembangkan suatu keterampilan, yaitu keterampilan membaca, yang dipentingkan bukan hanya cara pelajaran tersebut diajarkan, tetapi juga "cara pelajar menguasai keterampilan”. Dengan demikian, tindakan inovatif dalam pembelajaran membaca mengandung pengertian "cara atau prosedur pembelajaran membaca yang memungkinkan siswa dapat berlatih membaca melalui proses yang benar".

Menurut Tompkins dan Hoskisson (1995:32-56), dalam penerapannya, proses pada pembelajaran membaca mencakup tahaptahap prabaca, membaca, merespon, menggali teks, dan memperluas interpretasi. Adapun Horowitz merinci fase-fase dalam proses membaca meliputi survey, question, read, dan recite (1996: 141). Ini berarti proses yang harus ditempuh adalah melakukan membaca sekilas dahulu, membuat pertanyaan-pertanyaan, membaca secara intensif, kemudian menyampaikan isi bacaan. Tahapan yang hampir sama dirumuskan oleh Francis P. Robinson (Ackersold \& Field, 1997: 23), yaitu survey, question, read, recite/recall, dan review atau diistilahkan dengan SQ3R. Bedanya, ada tahap review, yaitu kegiatan mengulangi atau menelusuri kembali bagian-bagian tertentu dalam teks guna mendapatkan hal-hal penting yang seharusnya diingat. Jika diperhatikan, ketiga model pembagian tahap-tahap tersebut sama, yang pada intinya mencakup tahap prabaca, membaca, dan pascabaca. Pembagian tahap seperti ini pun dilakukan oleh Urquhart \& Weir (1998).

Tahap prabaca merupakan kegiatan yang dilakukan sebelum kegiatan inti membaca dalam rangka membangun pemahaman pembaca mengenai isi teks. Kegiatan prabaca dapat dilakukan dengan cara. Pertama, berupa pemberian gambaran awal oleh guru, yakni pemberian informasi yang berkaitan dengan isi teks kepada siswa. Menurut penelitian Smith Hilton (Bernhardt, 1991: 45) cara ini hanya efektif jika teksnya memuat ide yang rumit (cerita yang kompleks) atau memuat informasi yang baru. Adapun penelitian Ackersold (Ackersold \& Field, 1997: 33) menemukan bahwa dengan memberikan gambaran awal cerita dapat membantu siswa menyimpulkan isi bacaan, namun cara tersebut hanya dilakukan sesekali saja karena tindakan itu cenderung membuat siswa bergantung pada guru. Yang kedua, berupa pemetaan semantik, yaitu kegiatan memperkenalkan kosa kata yang terdapat dalam teks dan dapat menggugah skemata siswa berkaitan dengan topik bacaan. Karenanya guru harus mengidentifikasi katakata kunci yang mewakili topik-topik pada teks dan menyampaikan daftar kata tersebut di papan tulis. Selanjutnya dilakukan diskusi pada siswa mengenai hubungan antarkata kunci dengan membuat semacam diagram. Mengenai keefektifan cara ini, penelitian Keally, Bakriwala, \& Sheridan (2003) mendapati fakta pada pelaksanaanya pemetaan semantik juga menimbulkan ketergantungan siswa pada peran guru karena diskusi harus dipimpin dan dikontrol oleh guru. Ketiga, berupa pengadaan pertanyaan awal atau pertanyaan pemandu, yaitu kegiatan perumusan pertanyaanpertanyaan tentang isi teks setelah siswa melakukan survey atau membaca sekilas. Pertanyaan-pertanyaan tersebut untuk membantu pemusatan perhatian siswa pada saat melakukan kegiatan inti membaca. Keempat, berupa pengadaan dramatisasi atau simulasi, yaitu guru menggambarkan sebagian aksi dan situasi yang dikembangkan dalam cerita, kemudian dilakukan dramatisasi oleh siswa sesuai kemampuan dan pemahaman mereka. Sesudah itu, guru memberikan kesempatan pada siswa untuk membaca cerita yang sebenarnya. Menurut pendapat Glazer (1992: 64) cara ini memang mampu menarik perhatian siswa, namun penerapannya terbatas untuk teks naratif serta membutuhkan waktu yang cukup banyak.

Tahap membaca, yaitu kegiatan membaca yang sesungguhnya atau kegiatan inti membaca yang dalam membaca intensif, kegiatan tersebut dilakukan dengan kondisi diam atau tidak bersuara. Artinya, selama membaca yang bergerak adalah mata sesampai 
pembaca tidak boleh menyuarakan teks karena gerak mata lebih cepat berdasarkanpada gerak bibir. Pada tahap ini beberapa strategi dan kegiatan dapat digunakan untuk meningkatkan pemahaman siswa. Pemanfaatan pertanyaan awal dilakukan untuk memandu pembaca mengingat bagian-bagian penting dalam teks.

Tahap pascabaca, yaitu kegiatan yang dilakukan setelah membaca untuk membantu siswa dalam mengintegrasikan informasi baru ke dalam skemata yang sudah ada. Selain itu, kegiatan pascabaca dapat memperkuat dan mengembangkan hasil belajar yang diperoleh sebelumnya. Ada beberapa kegiatan dan strategi yang dapat dilakukan siswa setelah membaca, yaitu mengajukan pertanyaan, memperluas kesempatan belajar, menuturkan kembali isi bacaan, mengaplikasikan dalam praktik, dan mengadakan pementasan.

\section{KESIMPULAN}

Berdasarkan hasil deskripsi setiap siklus maupun antarsiklus dapat dirumuskan simpulan penelitian sebagai berikut: (1) pembuatan pertanyaan awal pada kegiatan prabaca dapat meningkatkan keaktifan dan motivasi siswa dalam pembelajaran membaca intensif, (2) pembuatan pertanyaan awal dapat meningkatkan kemampuan memamahi bacaan pada siswa kelas VIII C SMP Penda Mojogedang; (3) pembuatan pertanyaan awal dapat dilakukan secara efektif bila didasarkan berdasarkan hasil membaca sekilas isi teks, bukan hanya membaca judul dan subjudul teks; dan (4) pembuatan pertanyaan awal yang dilakukan di bawah bimbingan guru dan atau bersama-sama teman yang setara kemampuannya memungkinkan dihasilkannya pertanyaan awal yang relevan dengan isi teks dan mencapai tingkat pemahaman. Oleh karena itu, peneliti mengajukan saran sebagai berikut: (1) hendaknya guru Bahasa Indonesia melakukan pembelajaran membaca dengan mengikuti proses yang benar, yaitu ada tahap prabaca, tahap membaca, dan tahap pascabaca. Selama ini prosedur membaca yang umum diterapkan adalah tanpa melalui tahap prabaca; dan (2) Hendaknya guru Bahasa Indonesia senantiasa menerapkan berbagai strategi pembelajaran pada tahap prabaca sesampai memungkinkan siswa dapat mengaktivasi pengetahuan awalnya mengenai materi bacaan.

\section{Ucapan terima kasih}

Saya menyampaikan terima kasih kepada Dekan FKIP Universitas Sebelas Maret yang telah mendanai pelaksanaan penelitian ini. Selain itu, saya sampaikan terima kasih kepada Kepala dan Guru Bahasa Indonesia SMP Penda Mojogedang, Kabupaten Karanganyar yang telah bekerja sama dalam melaksanakan tindakan penelitian.

\section{DAFTAR PUSTAKA}

Ackersold, J. A., \& Field, M. L. (1997). From Reader to Reading Teacher: Issues and Strategies for Second Language Classrooms. New York: Cambridge University Press.

Bangert-Drowns, R.L., Kulik, J.A., \& Morgan, M. (1991). "Effect of Frequent Classroom Testing”, Dalam Journal of Educational Research, Vol. 85, Hal. 89-99

Bernhardt, E. (1991).Reading Development in a Second Language. Norwood, NJ: Ablex.

Bloom, B.S., et al. (1984). Taxonomy of Educational Objectives. Book 1: Cognitive Domain. White Plains, New York: Longman.

Brown, H. Douglas. (2001). Teaching by Principles: An Interactive Approach to Language Pedagogy. Englewood Cliffs, New Jersey: Prentice Hall Regents.

Carrell, P. L. (1999). "Metacognitive Awareness and Second Language Reading". Dalam Modern Language Journal, Vol.73, Hal.121-133.

Devine, J. (1993). "The Role of Metacognition in Second Language Reading and Writing", Dalam Reading in the Composition Classroom, J. G. Carson \& I. Leki (Eds.), Hal. 105-127. Boston, 
MA: Heinle \& Heinle.

Dole, H., Valencia, W., Greer, B., \& Waldrop, K. (1991). "Effects of Two Types of Prereading Instruction on the Comprehension of Narrative and Expository Text', Dalam Reading Research Quarterly, Vol. 26, Hal. 142159.

Frase, L.T., Patrick, E., \& Schumer, H. (2000). "Effect of Question Position and Frequency upon Learning from Text under Different Levels", Dalam Journal of Educational Psychology. Vol. 61(1), Hal. 52-56.

Glazer, S. M. (1992). Reading Comprehension: Self-monitoring Strategies to Develop Independent Readers. New York: Scholastic Professional Books.

Hartley, J., \& Davies, I.K. (2006). "Preinstructional Strategies: The Role of Pretest, Behavioral Objectives, Overviews and Advance Organizers". Dalam Review of Educational Research, Vol. 46, Hal. 239-265.

Harvey, Stephanie \& Goudvis, Anne. (2007). Strategies That Work: Teaching Comprehension for Understanding and Engagement (Second Edition). Portland: Stenhouse Publisher

Horowitz, Daniel. (1996). "Process, not Product: Less than Meets the Eye", Dalam TESOL Quarterly. Vol. 20 (1), Hal. 141- 149.

Keally, William A., Bakriwala, Darshan J., \& Sheridan, Philip B. (2003). "Counter Effects between an Adjunct Map and Prequestions", Dalam Educational Technology Research and Development, Vol. 51, No. 2. Hal. 112123

Pressley, M., Wood, E., Woloshyn, V. E., Martin, V., King, A., \& Deborah, M.(2001). "Encouraging Mindful Use of Prior Knowledge: Attempting to Construct Explanatory Answers Facilitates Learning", Dalam Educational Psychologist, Vol. 27,
No. 1, Hal. 91-109

Readence, J. E., Moore, D. W. \& Rickelman, R. J. (2000) Prereading Activities for Content Area Reading and Learning (Third Edition), International Reading Association, Inc.

Rickards, J.P. (1976). "Type of Verbatim Question Interspersed in Text: A New Look at the Position Effect", Dalam Journal of Reading Behavior, Vol. 8, Hal.37-45.

Shanahan, Timothy. (1997). "Effect of Pertanyaan awals on Delayed Retention of Prose Material", Dalam Journal of Educational Psychology, Vol. 61, Hal. 241-259.

Solan, H. A., Shelley-Trembay, J. F., Hansen, P. C., \& Larson, P.. (2007). "Is there a Common Linkage among Reading Comprehension, Visual Attention, and Cognitive Processing?", Dalam Journal of Learning Dissabilities, Vol. 40, No. 3, 270-278.

Thalheimer, Will. (2003). "The Learning Benefits of Questions". Dalam A WorkLearning Research Publications, November 31

Tompkins, Gail E. \& Hoskisson, Kenneth.(1995). Language arts: Content and Teaching Strategies. Englewood Cliffis, New Jersy: Prentice-Hall, Inc.

Urquhart, A. H., \& Weir, C. (1998). Reading in a Second Language: Process, Product, and Practice. New York: Longman.

Watts, G.H., \& Anderson, R. C. (2001). "Effects of Three Types of Inserted Questions on Learning from Prose". Dalam Journal of Educational Psychology, Vol. 62, Hal. 387-394. 